\title{
Structure and succession of Lasius s. str. (Hymenoptera: Formicidae) assemblages in a Finnish sand dune area - reassessment after taxonomic revisions of the subgenus
}

\author{
Wojciech Czechowski, Wiesława Czechowska \& Kari Vepsäläinen
}

Czechowski, W., Czechowska, W. \& Vepsäläinen, K. 2005: Structure and succession of Lasius s. str. (Hymenoptera: Formicidae) assemblages in a Finnish sand dune area - reassessment after taxonomic revisions of the subgenus. Entomol. Fennica 16: 2-8.

Gallé (1991) described the structure of ant assemblages along a successional gradient of sand dune habitats in southern Finland. The work was immediately succeeded by two revisions where two of the most abundant species on the sand dunes were split into two and three species respectively (Seifert 1991, 1992). On the basis of the revised taxonomy and our present work, Gallé's Lasius (s. str.) alienus (Först.) on the dunes is L. psammophilus Seifert, and his $L$. (s. str.) niger (L.) includes two sibling species, L. niger and L. platythorax Seifert. We reassess the relative abundances of the Lasius s. str. species and their nest sites in the successional habitats of the dunes in the light of the present taxonomic knowledge.

W. Czechowski \& W. Czechowska, Laboratory of Social and Myrmecophilous Insects, Museum and Institute of Zoology, Polish Academy of Sciences, Wilcza St 64, PL-00-679, Poland; E-mail: wcz@robal.miiz.waw.pl; w.czechowska (a)robal.milz.waw.pl

K. Vepsäläinen, Department of Biological and Environmental Sciences, $P . O$. Box 65, FIN-00014 University of Helsinki, Finland: E-mail: kari.vepsalainen @helsinki.fi

Received 13 May 2004, accepted 25 August 2004

\section{Introduction}

Among the studies on the structure and structuring of ant assemblages in northern Europe, Gallé's (1991) stands out in focusing on sand dunes, microclimatically extreme and rare habitats in Finland. In the dunes of Hanko Peninsula, southern Finland, Gallé reported 24 species of ants - later, a few additional species have been added to the local fauna (see Czechowski \& Rotkiewicz 1997, Czechowski 1999, 2000, 2001, Czechowski \& Vepsäläinen 2001, Czechowski et al. 2002).
Of the species recorded by Galle (1991), Lasius alienus (Först.) was the most abundant one at the scale of the whole study - a much less abundant species was $L$. niger (L.). Gallé assessed L. alienus the role of pioneer species in the assembly process of the sand dunes, in the same vein as Boomsma \& Van Loon (1982) classified L. niger in the Dutch sand dune succession. Soon after the publication of Gallé's study, revisions of the subgenus Lasius s. str. revealed that these two species actually consisted of three and two, respectively, morphologically similar species. On the basis of habitat and subtle morphological dif- 
ferences, Seifert (1991) split L. niger into two species, the other one being named L. platythorax Seifert. Similarly, he (Seifert 1992) split L. alienus into three species, thus adding to the subgenus L. psammophilus Seifert and L. paralienus Seifert.

The revision caused an enigmatic situation as comes to studies on ant assemblages (Radchenko et al. 1999a, b): what are the roles of each of the two species earlier called L. niger-when considered a collective species, one of the most ubiquitous and abundant ant species in Europe - in various habitats, and what is the identity of the pre-revision, more thermophilous L. alienus in Finland? On a local scale, we try to answer these questions by reassessing the relative abundances of the Lasius s. str. species in the sand dune area studied by Gallé (1991).

\section{Study area, material and methods}

We carried out the field work in July 2001, in the same site where Gallé had worked: the sand dune complex in Tvärminne village, Hanko Peninsula, southern Finland. We localised nests and collected samples in patches of the same successional habitats as studied (and characterised) by Gallé (1991):

- Stage 0: bare sand with no vegetation (Fig. 1a).

- Stages 1-2: with sparse coverage of the low grass Festuca ovina L. (Gallé provided no criterion to distinguish between stages 1 and 2) (Fig. 1b).

- Stage 3: with sparse coverage of the low sedge Carex arenaria L. (Fig. 1c).

- Stage 4: with sparse coverage of $F$. ovina, $C$. arenaria and, here and there, higher Leymus arenarius (L.); soil surface locally with patches of lichens and mosses (Fig. 1d).

- Stage 5: minimeadow with relatively dense and high Calamagrostis epigejos (L.) and Epilobium angustifolium L.; soil surface densely covered with lichens (Fig. 1e).

- Stage 6: minimeadow with high dense vegetation predominated by Calamagrostis epigejos (L.) and Phragmites australis (Cav.) (only one isolated patch, ca. $64 \mathrm{~m}^{2}$ ) (Fig. 1f).
- Stage 7: light pine (Pinus sylvestris L.) forest with dense coverage of lichens and mosses, and very poor grass and herb layer (Fig. 1g).

- Stage 8: light pine forest with well-developed grass, herb and heather layer, predominated by Calluna vulgaris (L.) (Fig. 1h).

Within the study area, stage 0 is commonplace and forms most extensive patches. Stages 1-4 are relatively common and distributed among the bare sand. Stages 5 and 6 are rare, isolated small patches in moderately damp depressions (especially stage 6); stage 5 is an open area overgrown only with sparse small pines, whereas stage 6 is surrounded by relatively humid mixed pine-deciduous (alder, aspen, birch) forest. Stage 7 is patchily distributed among treeless dunes, but also partly surrounds the open dunes. Stage 8 extensively surrounds the open dune area. Overall, the habitats form a mosaic of patches of varying sizes, rather than a spatially one-dimensional successional gradient.

We concentrated on locating nests of Lasius s. str. by searching for them visually and probing at all possible nest sites, in all classified habitats. After a nest was found, we recorded the nest site at the microhabitat level (in sand, in decaying wood, etc.). We paid special attention to recording the number of colonies instead of nest openings. This is especially relevant as comes to $L$. psammophilus (L. alienus sensu Gallé 1991), because its colonies often have fairly widely located entrances to the nest (see Markó \& Czechowski 2004). In total, several hectares of sand dunes were searched and 112 nest samples of Lasius s. str. were collected (Appendix 1). Because our purpose was to compare the relative abundances of the species within successional stages rather than compare their nest densities in different habitats, we did not record the areas studied per stage.

\section{Results}

Three species of the subgenus Lasius s. str. were found: L. psammophilus (stages 0-5 and 7), L. niger (stages 1-8) and L. platythorax (stages 4 and 6-8). L. psammophilus was found in all successional habitats, except the relatively humid meadow patch with dense and high vegetation 


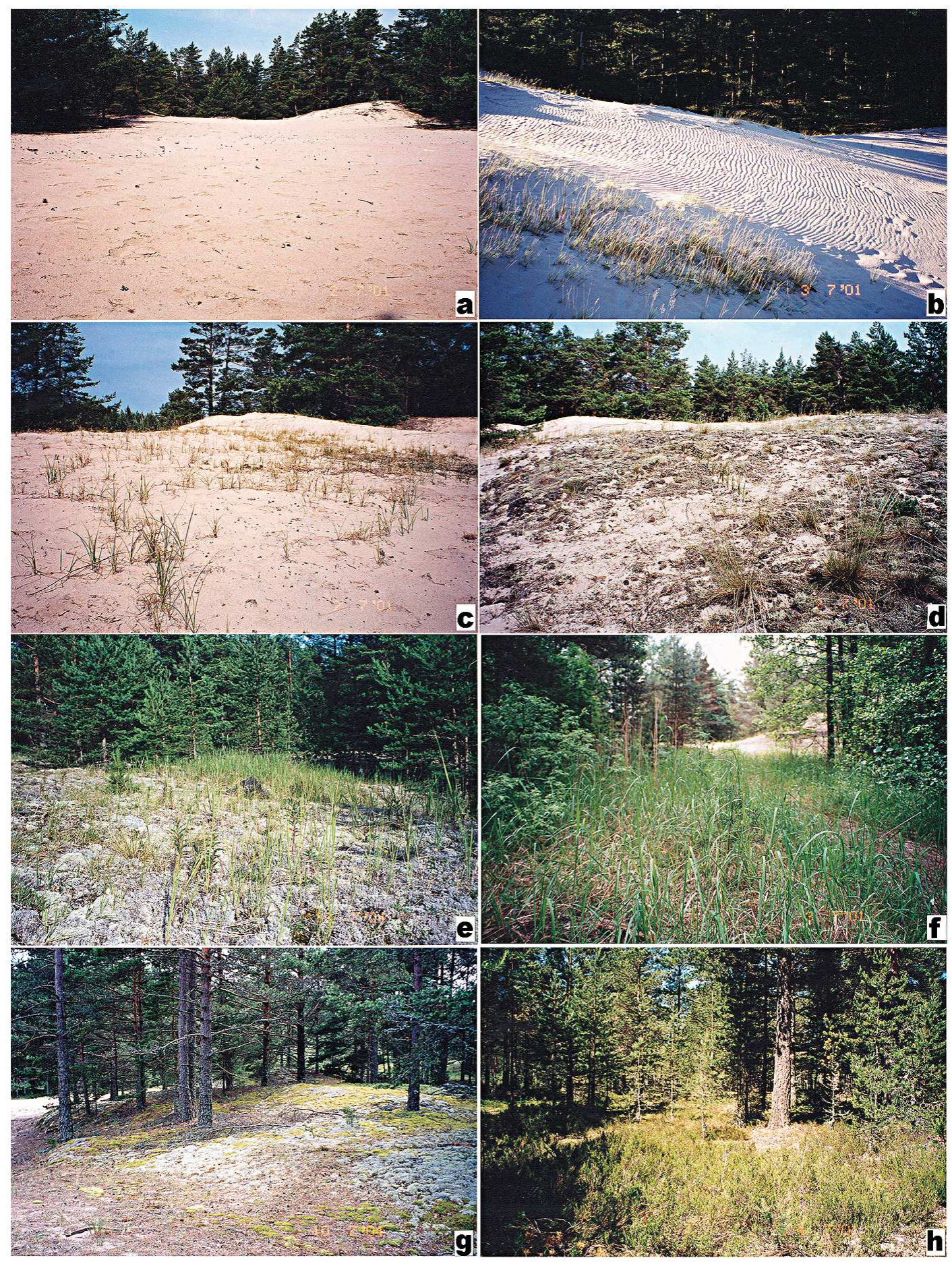

Fig. 1. Representative patches of the early- (a-d) and late- (e-h) successional sand dune stages studied in Tvärminne. - a. Stage 0. - b. Stages 1-2. - c. Stage 3. - d. Stage 4. - e. Stage 5. - f. Stage 6. - g. Stage 7. $-\mathrm{h}$. Stage 8. See section Study area, material and methods; photos W. Czechowski. 
Table 1. Number of colonies (and proportions in \%) of the three Lasius s. str. species along the successional habitat gradient. The successional stages have been grouped to form five main stages as comes to openness, temperature, humidity, and density and height of vegetation. Gallé (1991) did not give data on stage 0 . The null hypothesis of equal distribution of the species over the successional stages was rejected $\left(\chi_{(8)}^{2}=52.2, p=0.000\right)$.

\begin{tabular}{lllllll}
\hline Species/Stage & $0-3$ & 4 & $5-6$ & 7 & 8 & Total \\
\hline L. psammophilus & $19(83)$ & $14(58)$ & $2(29)$ & $12(44)$ & 0 & 47 \\
L. niger & $4(17)$ & $7(29)$ & $3(43)$ & $6(22)$ & $8(26)$ & 28 \\
L. platythorax & 0 & $3(13)$ & $2(29)$ & $9(33)$ & $23(74)$ & 37 \\
L. niger + L. platythorax & $4(17)$ & $10(42)$ & $5(72)$ & $15(55)$ & $31(100)$ & 65 \\
Gallé's L. niger & 0 & $2(9)$ & $1(50)$ & 0 & $2(100)$ & 5 \\
Gallé's L. alienus & $10(100)$ & $20(91)$ & $1(50)$ & $6(100)$ & 0 & 37 \\
\hline
\end{tabular}

(stage 6) and pine forest with rich understorey (stage 8). It clearly dominated in the proportion of Lasius s. str. nests at the warm and open end of the successional gradient, but was still the most abundant species in stage 7 , pine forest with sparse understorey and patches of bare sand. Within stage 0 the three nests of L. psammophilus were the only ant nests found.

$L$. niger was found in all of the successional stages except stage 0 . It did not dominate in any stage, but rather had a fairly even relative frequency distribution over the successional stages. On the contrary, L. platythorax was least evenly distributed over the stages, and it dominated in nest numbers in the final successional stage 8 -it was absent from stages $0-3$ with high dominance of L. psammophilus (Table 1; for raw, stage-level data, see Appendix 1).

The distribution of nest loci of the three species differed from each other (Table 2). All except one of the nests of $L$. psammophilus were found in mineral soil, $85 \%$ being located in bare sand.
Half of the nests of $L$. niger were in bare soil, and it was the only species found with earth mounds; only one nest was in decaying stump. Most of the nests of $L$. platythorax were built in decaying wood $(62 \%)$ or other organic material (humus, litter); $24 \%$ of the nests were in mineral soil (never with an earth mound), but rarely without cover (a piece of wood or a stone). The nest site diversity was highest in $L$. niger, and lowest in L. psammophilus.

\section{Discussion}

Gallé (1991) was interested in the community structure of the whole ant fauna on the dunes, and the nest densities of the species in each successional habitat. Thus, he did not provide the exact numbers of nests in his work, but on the basis of his table 2 we could assess the number of nests per species along the main successional stages (as grouped in Table 1) - the total number

Table 2. Number of nests (and proportions in \%) of each Lasius s. str. species in different nest sites. Nests under stone or moss/lichen or piece of wood were all in soil, except one $L$. psammophilus nest in litter under stone and one $L$. platythorax nest in humus under piece of wood. The null hypothesis of equal distribution of the nest sites of the species was rejected $\left(\chi_{(12)}^{2}=94.7, p=0.000\right)$.

\begin{tabular}{llllllll}
\hline Species/Nest site & $\begin{array}{l}\text { Bare } \\
\text { soil }\end{array}$ & $\begin{array}{l}\text { Under } \\
\text { stone }\end{array}$ & $\begin{array}{l}\text { Under } \\
\text { moss/ } \\
\text { lichen }\end{array}$ & $\begin{array}{l}\text { Under } \\
\text { piece } \\
\text { of wood }\end{array}$ & $\begin{array}{l}\text { Earth } \\
\text { mound }\end{array}$ & $\begin{array}{l}\text { Humus/ } \\
\text { litter }\end{array}$ & $\begin{array}{l}\text { Decaying } \\
\text { wood }\end{array}$ \\
\hline L. psammophilus & $40(85)$ & $2(4)$ & $1(2)$ & $4(9)$ & 0 & 0 & 0 \\
L. niger & $14(50)$ & $1(4)$ & $2(7)$ & $6(21)$ & $4(14)$ & 0 & $1(4)$ \\
L. platythorax & $3(8)$ & $2(5)$ & 0 & $4(11)$ & 0 & $5(14)$ & $23(62)$ \\
\hline
\end{tabular}


of nests of Lasius s. str. was 42. On the basis of this, we compared the distribution of his $L$. niger and $L$. alienus with our distribution of $L$. niger + L. platythorax and L. psammophilus, respectively. The null hypothesis of no difference between Gallé's and our distributions could not be rejected: for 'niger', $\chi_{(4)}^{2}=4.0, p=0.41$, and for 'alienus' $\chi_{(3)}^{2}=5.1, p=0.17$. Thus, it seems plausible to conclude that Gallé's L. alienus is, after Seifert's (1992) revision of the subgenus, actually L. psammophilus in the studied Finnish dune area.

The collective species 'niger' by Gallé had its density peak at the other end of the succession, in stage 8 , followed by stage 6 . The small nest numbers in Gallé's study (and ours in stages 5 and 6) do not allow any conclusions about the identity of Gallé's 'niger' relative to the revised taxonomy, and he does not provide nest site data which could have helped.

Because we did not assess the nest density of the species, we were only able to compare the abundances of the species within each successional stage. Our results show that L. psammophilus is by far the predominant Lasius species in the combined stage 0 to 3 , followed by stages 4 and 7, whereas Gallé's nest-density data indicate that the species reaches its abundance peak in stage 7, the open pine forest with a poorly developed understorey, and a second peak in stage 4, in the open dune area with sparse coverage of grasses. Gallé did not provide any data on the earliest successional habitat, stage 0 . We found there only three nests of $L$. psammophilus. There must be a reason for any ant being able to nest in bare sand dunes. We suggest that to be the evidently well-developed root system of Pinus sylvestris, which provides a good supply of root aphids for ants to collect honey dew. The L. psammophilus nests found on 'bare sand' were close enough for the extensive pine-root system to be utilised by the ants. They were situated at a distance of 5-7 metres from the dune edge overgrown with pines.

The nest loci of the three species partially reflect their habitat distribution and availability of various sites. In agreement with Seifert's (1991) observations, L. psammophilus nested in mineral soil, as did L. niger that, however, also constructed soil mounds - a unique feature within the subgenus Lasius (Seifert 1991). L. platythorax nested predominantly in organic material, which also is in accordance with Seifert's findings. The three nests of $L$. platythorax in the warm and dry stage 4 also demand an explanation. The nests were located in pieces of decaying railway sleepers that are remnants of an old Soviet military railroad. Such organic pieces provide shelter and humidity in micro-scale, similar to nesting sites in the woods. It is true, however, that general habitat conditions of the stage 4 seemed to be clearly unfavourable for this species. Under the climate of Central Europe, L. platythorax never is found in such extreme habitats. We are possibly dealing here with a latitude-dependent habitat shift known in some ants: species with a more southern centre of distribution tend to live in Finland (and generally in northern Europe) in habitats which at least look warmer than the Central European habitats of the species (but actually they may be as warm as more shady sites in Central Europe; K. Vepsäläinen, unpubl.).

The collective species of 'alienus' now comprises of three species, of which only L. psammophilus has been recorded in Finland. The other two species, L. paralienus and especially $L$. alienus, are denizens of limestone substrate (Seifert 1992, Czechowski et al. 2002). Their status in Finland is not known, but there equivalent, suitable habitats are extremely rare.

Acknowledgements. The field investigations in Finland were made during a stay of W. Cz, at the Tvärminne Zoological Station of the University of Helsinki within the programme of scientific cooperation between the Polish Academy of Sciences and the Academy of Finland. The authors thank the referee for his comments on the ms which allowed us to specify more precisely some points of the paper.

\section{References}

Boomsma, J. J. \& Van Loon, A. J. 1982: Structure and diversity of ant communities in successive coastal dune valleys. - Journal of Animal Ecology 51: 957-974.

Czechowski, W. 1999: Lasius fuliginosus (Latr.) on a sandy dune - its living conditions and interference during raids of Formica sanguinea Latr. (Hymenoptera, Formicidae). - Annales Zoologici 49: 117 123.

Czechowski, W. 2000: Interference of territorial ant species in the course of raids of Formica sanguinea Latr. (Hymenoptera, Formicidae). - Annales Zoologici 50: $35-38$. 
Czechowski, W. 2001: Mixed colony of Formica pratensis Retz. + Formica cinerea Mayr + Formica sanguinea Latr. (Hymenoptera, Formicidae) and its presumed origin. - Annales Zoologici 51: 205-209.

Czechowski, W., Godzińska, J. A. \& Kozłowski, M. 2002: Rescue behaviour shown by workers of Formica sanguinea Latr., F. fusca L. and F. cinerea Mayr (Hymenoptera, Formicidae) in response to their nestmates caught by an ant lion larva. - Annales Zoologici 52 : 423-431.

Czechowski, W., Radchenko, A. \& Czechowska, W. 2002: The ants (Hymenoptera, Formicidae) of Poland. - MIZ PAN, Warszawa, 200+ 1 pp.

Czechowski, W. \& Rotkiewicz, W. 1997: Relations between Formica sanguinea Latr. and Formica cinerea cinerea Mayr (Hymenoptera, Formicidae) - an unusual form of dulosis. - Annales Zoologici 47: 469 478.

Czechowski, W. \& Vepsäläinen, K. 2001: Formica rufa L. indirectly protects $F$. fusca $\mathrm{L}$. against $F$. sanguinea Latr. raids (Hymenoptera, Formicidae). - Annales Zoologici 51: 113-119.

Gallé, L. 1991: Structure and succession of ant assem- blages in a north European sand dune area. - Holarctic Ecology 14: 31-37.

Markó, B. \& Czechowski, W. 2004: Lasius psammophilus Seifert and Formica cinerea Mayr (Hymenoptera: Formicidae) on sand dunes: conflicts and coexistence. - Annales Zoologici 54: 365-378.

Radchenko, A., Czechowska, W., Czechowski, W. \& Siedlar, E. 1999a: Lasius niger (L.) and Lasius platythorax Seifert (Hymenoptera, Formicidae) - a revolution in Polish myrmecological faunistics and zoocoenology? - Fragmenta Faunistica 42: 103-113.

Radchenko, A., Czechowska, W., Czechowski, W. \& Siedlar, E. 1999b: Four ant species, new to Poland, of the genus Lasius F. and new data on the occurrence of species recorded earlier (Hymenoptera, Formicidae). - Fragmenta Faunistica 42: 115-121.

Seifert, B. 1991: Lasius platythorax n. sp., a widespread sibling species of Lasius niger (Hymenoptera: Formicidae). - Entomologia Generalis 16: 69-81.

Seifert, B. 1992: A taxonomic revision of the Palaearctic members of the ant subgenus Lasius s. str. (Hymenoptera: Formicidae). - Abhandlungen und Berichte des Naturkundemuseums Görlitz 66: 1-67. 
Appendix 1. List of Lasius s. str. nest samples collected in the studied successional stages of sand dunes at Tvärminne, and the locations of nests.

\begin{tabular}{|c|c|c|}
\hline Stage & $\begin{array}{l}\text { Species } \\
\text { (Number of nests) }\end{array}$ & $\begin{array}{l}\text { Nest location } \\
\text { (Number of nests) }\end{array}$ \\
\hline 0 & L. psammophilus (3) & \multirow[t]{3}{*}{ In bare soil ( 23 ; stages $0-3$ and their species pooled) } \\
\hline $1-2$ & $\begin{array}{l}\text { L. psammophilus (5) } \\
\text { L. niger (3) }\end{array}$ & \\
\hline 3 & $\begin{array}{l}\text { L. psammophilus (11) } \\
\text { L. niger (1) }\end{array}$ & \\
\hline \multirow[t]{3}{*}{4} & L. psammophilus (14) & $\begin{array}{l}\text { In bare soil (11) } \\
\text { In soil under piece of wood (2) } \\
\text { In soil under stone (1) }\end{array}$ \\
\hline & L. niger (7) & $\begin{array}{l}\text { In bare soil (6) } \\
\text { In soil under piece of wood (1) }\end{array}$ \\
\hline & L. platythorax (3) & $\begin{array}{l}\text { In soil under piece of wood (2) } \\
\text { In decaying piece of wood (1) }\end{array}$ \\
\hline 5 & $\begin{array}{l}\text { L. psammophilus ( } 2) \\
\text { L. niger (2) }\end{array}$ & In bare soil $(4 ; L$. psammophilus and $L$. niger pooled $)$ \\
\hline 6 & $\begin{array}{l}\text { L. niger (1) } \\
\text { L. platythorax (2) }\end{array}$ & $\begin{array}{l}\text { In bare soil (1) } \\
\text { In decaying fallen branches (2) }\end{array}$ \\
\hline 7 & L. psammophilus (12) & $\begin{array}{l}\text { In bare soil ( } 8 \text { ) } \\
\text { In soil under piece of wood (2) } \\
\text { In soil under lichens (1) } \\
\text { In litter under stone (1) }\end{array}$ \\
\hline & L. niger $(6)$ & $\begin{array}{l}\text { In soil (1) } \\
\text { In soil with earth mound (2) } \\
\text { In soil under stone (1) } \\
\text { In soil under lichens (1) } \\
\text { In soil under moss (1) }\end{array}$ \\
\hline & L. platythorax (9) & $\begin{array}{l}\text { In decaying stump (4) } \\
\text { In bare soil (3) } \\
\text { In humus at stump (1) } \\
\text { In soil under stone (1) }\end{array}$ \\
\hline 8 & L. niger (8) & $\begin{array}{l}\text { In soil under piece of wood (5) } \\
\text { In soil with earth mound (2) } \\
\text { In decaying stump (1) }\end{array}$ \\
\hline & L. platythorax (23) & $\begin{array}{l}\text { In decaying stump or log (16) } \\
\text { In humus at stump (2) } \\
\text { In humus under pieces of wood (1) } \\
\text { In humus (1) } \\
\text { In litter (1) } \\
\text { In soil under piece of wood (1) } \\
\text { In soil under stone (1) }\end{array}$ \\
\hline
\end{tabular}

